ARTICLE

\title{
Seaweeds agarophytes and associated epiphytic bacteria along Alexandria coastline, Egypt, with emphasis on the evaluation and extraction of agar and agarose
}

Agarófitas marinas asociadas con bacterias epifitas de la costa de Alejandría, Egipto, con énfasis en la evaluación y extracción de agar y agarosa

\author{
Hassan A.H. Ibrahim ${ }^{1}$, Ehab A. Beltagy ${ }^{1}$, Nihal G. Shams El-Din ${ }^{2}$, \\ Gehan M. El Zokm³, Amany M. El-Sikaily ${ }^{4}$ and Gehan M. Abu-Elela ${ }^{1}$
}

\begin{abstract}
${ }^{1}$ Microbiology Department, National Institute of Oceanography and Fisheries (NIOF), Kayet Bay, El-Anfoushy, Alexandria, Egypt ${ }^{2}$ Hydrobiology Department, NIOF, Kayet Bay, El-Anfoushy, Alexandria, Egypt. drhassan19733@yahoo.com ${ }^{3}$ Marine Chemistry Department, NIOF, Kayet Bay, El-Anfoushy, Alexandria, Egypt

${ }^{4}$ Marine Pollution Department, NIOF, Kayet Bay, El-Anfoushy, Alexandria, Egypt

Resumen.- Se realizó un estudio de algas marinas en la costa de Alejandría para seleccionar una agarófita adecuada para la extracción y evaluación de las sustancias de agar y agarosa, además de estimar e identificar las bacterias epifitas asociadas con estas algas capaces de secretar paquetes de enzimas hidrolíticas degradantes de paredes celulares de algas. Un total de 13 muestras de algas se recolectaron durante primavera del 2012. Del total se obtuvieron 2 especies de Rhodophyta; Gelidium crinale y Pterocladiella capillacea, las cuales pueden ser explotadas para la producción de agar y agarosa. Se encontraron un total de 9 géneros de aislados bacterianos dominantes asociados con las diferentes muestras de algas. Estos fueron identificados como; Alcaligenes sp., Bordetella sp., Acinetobacter sp., Pseudomonas sp.1, Pseudomonas sp.2, Pseudomonas sp.3, Flavobacterium sp., Vibrio sp. y Vigribacillus sp. La especie con mayor capacidad de secretar un paquete de enzimas degradantes fue Vigribacillus sp. que fue aislada de P. capillacea cosechado en Western Harbor. Los hidratos de carbono, lípidos y proteínas totales se determinaron tanto en P. capillacea, como en el agar extraido, y agar Oxoid (material comercial de referencia). Además se estimaron algunos metales (cobre, cadmio, plomo, zinc, níquel, cromo, hierro, manganeso y arsénico) en las 3 muestras mencionadas. La resistencia de gel, temperatura de gelificación y fusión, además de la claridad y viscosidad de los extractos y agares Oxoid mostraron diferentes patrones. El contenido de sulfato del agar extraído fue ligeramente mayor que la de agar Oxoid, mientras que el contenido de piruvato mostró patrón inverso. El espectro FTIR del agar extraído indicó grupo metilado, lo que sugiere que el agar extraído de P. capillacea es un polisacárido altamente metilado por tanto de una alta gelificación.
\end{abstract}

Palabras clave: Bacterias epifitas, agarofitas, agar, agarosa

\begin{abstract}
A survey of seaweeds along Alexandria coastline was carried out to choose a suitable agarophyte for extraction and evaluation of the agar and agarose substances, in addition to estimate and identify the epiphytic bacteria associated with these seaweeds which are capable of secreting package of hydrolytic enzymes and hence degrading algal cell walls successfully. A total of 13 algal samples were collected during spring 2012. There were 2 Rhodophytes species; Gelidium crinale and Pterocladiella capillacea, which can be exploited for agar and agarose production. Nine dominant bacterial isolates were associated with the different algal samples; they were identified at genus level as; Alcaligenes sp., Bordetella sp., Acinetobacter sp., Pseudomonas sp.1, Pseudomonas sp.2, Pseudomonas sp.3, Flavobacterium sp., Vibrio sp. and Vigribacillus sp. The most superior species able to secrete a package of degrading enzymes was Vigribacillus sp. that was isolated from P. capillacea harvested from Western Harbor. The total carbohydrate, lipid and protein contents were determined in both P. capillacea and its agar, and in Oxoid agar (a reference commercial material). Some metals (copper, cadmium, lead, zinc, nickel, chrome, ferrous, manganese and arsenic) were also estimated in the 3 mentioned samples. The gel strength, gelling temperature and melting temperature besides the clarity and viscosity of extracted and Oxoid agars showed different patterns. The sulphate content of the extracted agar was slightly higher than that of Oxoid agar, while the pyruvate content showed inverse pattern. The extracted agar FTIR spectrum indicated methylated group, which proved that the agar extracted from P. capillacea is a highly methylated polysaccharide resulting in high gellation.
\end{abstract}

Key words: Epiphytic bacteria, agarophyte, agar, agarose 


\section{INTRODUCTION}

Seaweed surfaces provide a protected and nutrient-rich 'hot spot' for opportunistic bacteria that are abound wherever organic material is available (Armstrong et al. 2001). Marine macroalgae generally associate with specific bacterial communities that differe signicantly from those occurring in the surrounding seawater (Lachnit et al. 2009). Algal cell wall components and secondary metabolites can trigger specific interactions between seaweeds and beneficial bacteria (Lachnit et al. 2010). Seaweed-associated bacteria are important sources of fixed nitrogen and detoxifying compounds (Goecke et al. 2010). Besides being epiphytic on algal surfaces, bacteria also live inside the thallus. On the other hand, seaweed grazers or epiphytic bacteria capable of degrading algal cell walls can damage algal thalli and provide an entrance for pathogenic and opportunistic bacteria (Wang et al. 2008).

The Egyptian Mediterranean coast is highly diversified in seaweeds belonging to the 3 classes; Chlorophyceae, Phaeophyceae and Rhodophyceae. Aleem (1993) recorded 244 species at Alexandria shores, while there are many sites along the Mediterranean coast still unexploited although they sheltered large number of seaweeds (Shams El-Din \& El-Sherif 2012). However, the Rhodophyte Pterocladiella capillacea is the most abundant agarophyte growing along Alexandria shores. Huge masses of this species drift throughout the year (Rao \& Bekheet 1976). The alga grows profusely along the sub-littoral belt of the rocky coast of Egypt (Nasr et al. 1966) and is the raw material for agar manufacture in Alexandria (Rao \& Bekheet 1976). In general, the chemical composition of seaweeds reveals their richness in polysaccharides, minerals and vitamins (Mabeau \& Fleurence 1993). However, the major polysaccharides of seaweeds are either structural (contributing to the fiber content), which are analogous to terrestrial plants and are mainly celluloses, hemicelluloses and xylans or storage components, including alginates (in brown algae), agars, and carrageenans (in red seaweeds) (MacArtain et al. 2007). Agars consist of alternating D- and Lgalactopyranose units (MacArtain et al. 2007). The species used in agar production give rise to products with difference in their properties. For this reason, it is customary to indicate the origin of raw material, such as Gelidium agar, Gracilaria agar, Pterocladiella agar, etc. In Pterocladiella capillacea, agar accumulates in the cell walls of the alga. It is used primarily as a gelatin in food, and can also be used in laboratory settings as a culture medium to support the growth of cells in experiments (Freile-Pelegrin et al. 1996, Sebaaly et al. 2012). Made up of $80 \%$ fiber, it is an excellent laxative agent (Glicksman 1983). It is also used to prepare dietetic formulas and food for diabetics (Armisén \& Galatas 1987). According to Rao \& Bekheet (1976), Pterocladiella is an excellent seaweed for agar-agar production, and it has been observed that the gel strength of the Egyptian agar is higher than that of the known agar samples collected from other countries, including Japan and the United States. However, the available data concerning the production of agar from this agarophyte or other ones in Egypt are still not satisfactory and much information is lacking about the process and only very few studies have been conducted (Rao \& Bekheet 1976).

The aim of the current study was to investigate the seaweeds occurring along the Alexandria coastline to choose a suitable agarophyte for extraction and evaluation of the agar and agarose substances, in addition to estimate and identify the epiphytic bacteria associated with these seaweeds which are capable of secreting package of hydrolytic enzymes and so degrading algal cell walls successfully.

\section{MATERIAL AND METHODS}

\section{STUdy AREA}

A survey was conducted during 2012 covering 6 sites along Alexandria coast with depths $(0.5-1 \mathrm{~m})$, namely: AbuQir Bay (St.I), El Silsila (St. II), Eastern Harbor (St. III), El Anfoushy (St. IV), Western Harbor (St. V) and El Dekheila Harbor (St. VI) extending from latitude $31^{\circ} 16^{\prime} \mathrm{N}$ and longitude $30^{\circ} 03^{\prime} \mathrm{E}$ to $29^{\circ} 47^{\prime} \mathrm{N}$ and $31^{\circ} 10^{\prime} \mathrm{E}$ (Fig. 1). All these stations are subjected to different types of land-based activities and/ or freshwater input (Shams El-Din \& Dorgham 2007, Abdallah 2008), in addition to shipping activities and fisheries in the 3 harbors (St. III \& St. V \& St. VI) (Zaghloul 1994, Zaghloul et al. 1995, Shams El-Din et al. 2007).

\section{SAMPles COLlection}

A total of 13 algal samples were collected during spring (6 April, 2012) at these sites. Afterwards, another trip was conducted to collect only the agarophyte during early summer (11 June, 2012). The samples were collected by hand at the depths $(0.5-1.0 \mathrm{~m})$, washed with sea water at the sampling sites to remove the adhered sediments, impurities and epiphytes, separated in polyethylene bags 


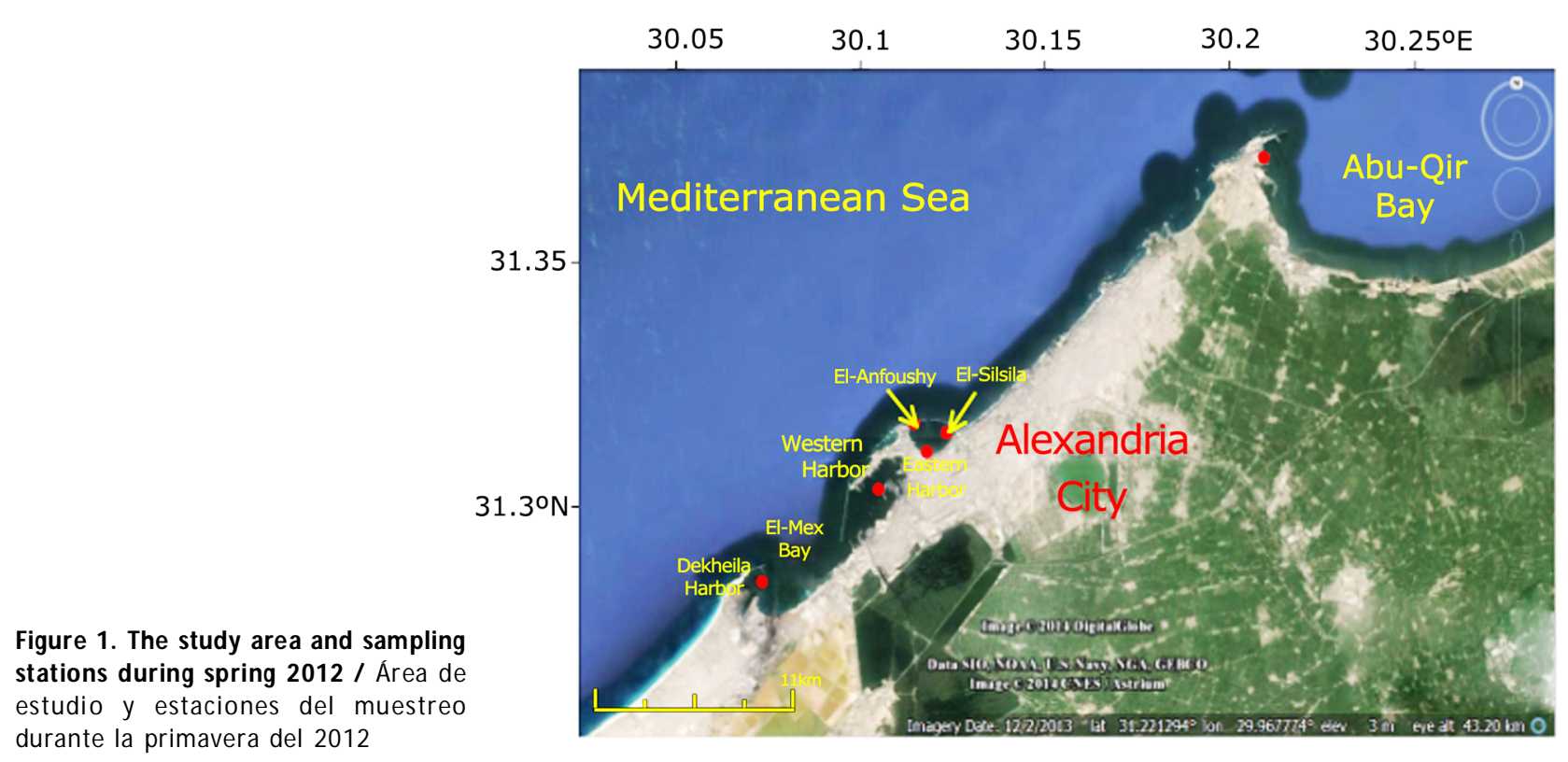

and stored under refrigeration $4^{\circ} \mathrm{C}$. Quick rinsing of the algae with tap water was carried out in the laboratory on the same day to get rid of the remaining impurities and epiphytes. Herbarium sheets with a preliminary identification of separated species were done and/or preserved in $4 \%$ formalin. Microscopic identification of the investigated algae was carried out according to Aleem (1993) and Braune (2008).

\section{COUNTING, ISOLATION AND IDENTIFICATION OF MARINE BACTERIA}

Sea water agar medium according to Zobell (1946) was used for the enumeration and isolation of viable aerobic heterotrophic bacteria associated with algae. Serial dilutions from $10^{-2}$ through $10^{-4}$ were made using filtered sterilized sea water. A portion $(0.1 \mathrm{ml})$ from each appropriately diluted sample was used to inoculate plates, which were incubated at $30^{\circ} \mathrm{C}$ for $24-48 \mathrm{~h}$ and later were counted. The pure dominant colonies obtained were transferred to fresh slants. Dominant bacteria were stained for Gram reaction, and then examined microscopically. Colony morphology characters such as size, appearance, configuration, and elevation were examined on nutrient agar plates after $24 \mathrm{~h}$ incubation. Cell morphology was microscopically examined after Gram staining of $24 \mathrm{~h}$ old cultures. Gram reaction was confirmed by potassium hydroxide as follows: a loopfull of bacterial colony was mixed with a drop of $3 \%$ potassium hydroxide on a clean glass slides. The absence of slimy substance confirms a
Gram-positive reaction. Each of the selected bacterial strains was examined for several characters; catalase, oxidase, indole production, methyl red and VogesProskaur tests, $\mathrm{H}_{2} \mathrm{~S}$ precipitation, nitrate reduction, citrate utilization, acid production, etc. Degradation of gelatin, casein, starch, chitin, etc., was also achieved. Finally, these isolates were identified according to tests in Cheesbrough (1985), Williams et al. (1989) and Cowan \& Steel (1993).

\section{Agar extraction}

A total of $300 \mathrm{~g}$ of the air-dried agarophyte (Pterocladiella capillacea) was washed twice with hot water at $40^{\circ} \mathrm{C}$ and then boiled for $2 \mathrm{~h}$ at $30 \mathrm{lb} / \mathrm{in}^{2}$ using 4.5 liters of water (weed-to-water ratio, 1:15). The residue after $2 \mathrm{~h}$ of extraction was separated from the solution by filtering through a 'double cloth' and squeezing the cloth as much as possible to remove liquid. The filtrate was collected in trays, allowed to set to a gel, and then kept in a cold chamber for $24 \mathrm{~h}$. After thawing, the gel was washed several times, bleached with $1.0 \% \mathrm{NaClO}_{2}$ solution, and then treated with dilute $\mathrm{H}_{2} \mathrm{O}_{2}$ solution. The sheets were then washed several times with water before being dried (Rao \& Bekheet 1976). Samples were extracted within 3 weeks to prevent any possible agar degradation upon prolonged seaweed storage according to Villanueva et $a l$. (2010). The yield of dried agar was calculated from the original dried sample weight. 


\section{DETERMINATION OF EXTRACTED AGAR PROPERTIES}

\section{CARbOHYDRATES, PROTEINS AND LIPIDS ESTIMATION}

Algal sample was dried at room temperature $\left(25^{\circ} \mathrm{C}\right)$ to a constant weight and then ground to fine powder. For each component, $1 \mathrm{~g}$ dry weight was taken. Total carbohydrates (TCHs) content was determined according to the phenol-sulphuric acid method investigated by Strickland \& Parsons (1972) using double-beam Shimadzu spectrophotometer (visible-UV model 150-02) at $490 \mathrm{~nm}$. The accuracy of the method for the determination of TCHs was measured by triplicate analysis of blanks, Standard (D- Glucose) and samples. The results of quality control measurements represented $10 \%$ of the total analytical load. The limit of detection was $0.1 \mu \mathrm{g} \mathrm{L}^{-1}$. Total proteins were estimated using the Biuret method of Raymont et al. (1964) using a double beam UV/V Spectrophotometer (SPEKOL 1300 Analytikjena) at $546 \mathrm{~nm}$. Total lipids (TL) were estimated according to Bligh \& Dyer (1959) based on mixing 1:1 (v/v) chloroform/ methanol, which allows extraction of both polar and nonpolar lipids. The lipids in the chloroform layer were isolated and measured using double-beam Shimadzu spectrophotometer (visible-UV model 150-02) at $525 \mathrm{~nm}$. The results of the 3 components were expressed as $\mathrm{mgg}^{-1}$ dry weight. The same procedures were applied for dry extracted agar at $70^{\circ} \mathrm{C}$ and manufactured Oxoid agar (used as a reference commercial material). The accuracy of the method for the determination of proteins and lipids was measured by triplicate analysis of blanks and samples. The results of quality control measurements represented $10 \%$ of the total analytical load.

\section{MAJOR ELEMENTS CONTENT}

For major elements (calcium, magnesium, sodium and potassium) analysis, dried algal sample to a constant weight $\left(60^{\circ} \mathrm{C}\right)$, dried extracted agar and Oxoid agar were homogenized by crushing each sample in a porcelain pestle and mortar, and kept away from metallic materials and dusty conditions to avoid contamination. One gram dry weight of each sample was acid digested in $5 \mathrm{ml}$ concentrated $\mathrm{HNO}_{3}$ in a Teflon cups. Digested samples were filtered through an acid-washed filter (Whatman GF/ C) and diluted to $25 \mathrm{ml}$ with double distilled water. All glassware, plastic and Teflon devices were thoroughly acid washed according to Haritonidis et al. (1983) and Mohamed \& Khaled (2005). Moreover, Na and K were measured using a Flame Photometer (JENWAY PEP7). Calcium and $\mathrm{Mg}$ were determined volumetrically using EDTA standard solution Erio-Chrome $\mathrm{T}$ and Murexide indicators (APHA 1975). The concentrations were expressed as $\mathrm{mgg}^{-1}$.

\section{Trace Metals}

The concentrations of the trace metals: $\mathrm{Cu}, \mathrm{Cd}, \mathrm{Zn}, \mathrm{Ni}, \mathrm{Cr}$, $\mathrm{Pb}, \mathrm{Fe}$ and $\mathrm{Mn}$ were determined according to Haritonidis et al. (1983) and Mohamed \& Khaled (2005) using Atomic absorption AAS/flame mode (Shimadzu AA-6800) for all trace metals except As. Hydride/ASS (HVG-1; Shimadzu AA-6800) was used for determination. Working standards (Merck, Germany) of the major and trace elements were prepared by diluting concentrated stock solutions with deionized water. To monitor the quality of chemical analysis and examine the accuracy of the data, reference materials SD-M-2/TM and IAEA/356 were analyzed with the digested seaweeds solutions during the course of analysis. The measured concentrations of trace metals were within the range of certified values with a recovery within $\pm 10 \%$ (Table 1 ), whereas precision was agreed to be within $10 \%$ for triplicate measurements.

\section{Physical and Rheological Properties of agar}

Extracted agar was dried at $70^{\circ} \mathrm{C}$ and then was grounded in a grounder to fine powder. Both extracted and Oxoid agars (Oxoid Co., UK) were reconstituted into $1.5 \% \mathrm{w} / \mathrm{v}$ solutions to measure rheological properties.

Moisture content: One gram of dried extracted agar and Oxoid agar was heated $12 \mathrm{~h}$ at $37^{\circ} \mathrm{C}$ to constant weight and the moisture content was calculated as the percentage of the lost weight to the initial weight.

Table 1. Results of validation study for heavy metals concentrations $\left(\mu \mathrm{g} \mathrm{g}^{-1}\right)$ in reference material (SD-M -2/ TM) analyzed together with samples / Resultados del estudio de validación para las concentraciones de metales pesados $\left(\mu \mathrm{g} \mathrm{g}^{-1}\right)$ en material de referencia (SD-M-2 / TM) analizado junto con las muestras

\begin{tabular}{cccccr}
\hline Element & $\begin{array}{c}\text { Wave } \\
\text { length } \\
\text { (nm) }\end{array}$ & LOD & $\begin{array}{c}\text { Certified } \\
\text { values }\end{array}$ & $\begin{array}{c}\text { Found } \\
\text { values }\end{array}$ & $\begin{array}{c}\text { Recovery } \\
\%\end{array}$ \\
\hline $\mathrm{Cu}$ & 324.7 & 0.008 & 32.7 & 31.1 & 95.11 \\
$\mathrm{Cd}$ & 228.8 & 0.005 & 0.11 & 0.12 & 109.09 \\
$\mathrm{Zn}$ & 213.9 & 0.002 & 74.8 & 78.0 & 104.28 \\
$\mathrm{Ni}$ & 232 & 0.02 & 56.1 & 53.9 & 96.08 \\
$\mathrm{Cr}$ & 357.9 & 0.015 & 77.2 & 74.9 & 97.02 \\
$\mathrm{Fe}$ & 248.3 & 0.025 & 27.1 & 26.46 & 97.64 \\
$\mathrm{Mn}$ & 279.5 & 0.01 & 12 & 11.4 & 95.00 \\
\hline
\end{tabular}

$\mathrm{LOD}=$ the detection limit of the trace elements 
Ash content: One gram of dried extracted agar and Oxoid agar was heated at $40^{\circ} \mathrm{C}$ for $48 \mathrm{~h}$ and the remained material was weighted again and the ash content was calculated as percentage of the remained dried weight to the initial weight.

pH: The pH meter (Model HANNA PHep) was adjusted to 7.4 and then applied to the $1.5 \% \mathrm{w} / \mathrm{v}$ solution of both extracted agar and Oxoid agar and the $\mathrm{pH}$ was determined at room temperature $\left(25^{\circ} \mathrm{C}\right)$.

\section{Gel STRENGTH MEASUREMENT}

The gel strength was measured in dry extracted agar and Oxoid agar after gelling overnight at room temperature $\left(25^{\circ} \mathrm{C}\right)$ by measuring the load causing the cylindrical plunger $\left(1 \mathrm{~cm}^{2}\right.$ cross-section) to break a standard gel (Armisén \& Galatas 1987, Freile-Pelegrin et al. 1996). The weight was added sequentially to the plunger, beginning with $100 \mathrm{~g}$, until the plunger broke the gel surface. The time between the addition of the last weight and the point where the plunger reached the bottom of the beaker was determined using 3 replicates, for each sample (Praiboon et al. 2006). The gel strength for the dry extracted agar and Oxoid agar was also measured at temperature of 85 and $90^{\circ} \mathrm{C}$. The gel strength was expressed as the $\mathrm{gcm}^{-2}$ that the gel resisted for $20 \mathrm{~s}$.

\section{GeLling AND MELTING TEMPERATURe}

Gelling temperature was obtained by the addition of $10 \mathrm{ml}$ hot agar solution into a test tube $(2.3 \mathrm{~cm}$ diameter, $6 \mathrm{~cm}$ height). A glass bead ( $5 \mathrm{~mm}$ diameter) was placed in the test tube. The tube was tilted up and down in a water bath at room temperature until the glass bead ceased moving. The gel temperature in the tube was immediately measured introducing a precision thermometer $\left(0.1^{\circ} \mathrm{C}\right.$ divisions). Melting temperature of the gel in a test tube ( $2.3 \mathrm{~cm}$ diameter, $16.5 \mathrm{~cm}$ height) was measured by placing an iron bead ( $9 \mathrm{~mm}$ diameter) on the gel surface. The test tube was clamped in a water-bath and the temperature rose from 50 to $100^{\circ} \mathrm{C}$; melting point was recorded with a precision thermometer when the bead sank into the solution (Freile-Pelegrin et al. 1996).

\section{VISCOSITY}

An Ostwald's Viscometer measured apparent viscosity. Spindle No. 1 at $1500 \mathrm{rpm}$ (round per minutes) was used for measuring apparent viscosities of agar samples (1.5\% in deionized water) at $80^{\circ} \mathrm{C}$ (Praiboon et al. 2006).

\section{Clarity}

The clarity of the gel solution was determined according to Tang et al. (2001). Sodium chloride (20 - $450 \mathrm{mM})$ was added to the prepared gel solutions of extracted agar and manufactured Oxoid agar. Each solution was continuously stirred for 2 to $3 \mathrm{~min}$ and poured into 6 polystyrene shape cuvettes of $4.5 \mathrm{ml} 1 \mathrm{x} 1 \mathrm{~cm}^{2}$. All cuvettes containing the gels were cooled in room temperature $\left(25^{\circ} \mathrm{C}\right)$ for $24 \mathrm{~h}$. Light absorbance of the gel solutions was measured at $\lambda$ $490 \mathrm{~nm}$ with a spectrophotometer (Model Japanese Spekoll 11), using water as the reference. The mean absorbance at $\lambda 490 \mathrm{~nm}$ of gels cooled in air was determined from 3 replicates. Small absorbance represents little turbidity and good clarity of the gels (Tang et al. 2001). The results of clarity were expressed as nepholes.

\section{SulPhate AND PYRUVATE}

The percent of sulphate was determined by hydrolyzing $1 \mathrm{~g}$ of agar powder in $10 \mathrm{ml} \mathrm{HNO}_{3}$ in $100 \mathrm{ml}$ Kjeldahl flasks, resulting in complete hydrolysis of the ester sulphate followed by quantitative precipitation with barium chloride of the liberated sulphate. The precipitates were collected on ash-free gravimetric filters, dried, ignited and weighed on a precision balance $(0.0001 \mathrm{~g})$. The weight of the obtained barium sulphate, multiplied by 0.4116 , gave the equivalent of sulphate (Freile-Pelegrin et al. 1996). According to Freile-Pelegrin et al. (1996), the percent of pyruvate was determined by hydrolyzing $0.5 \mathrm{~g}$ of agar powder in oxalic acid $0.02 \mathrm{M}$ following the spectrophotometric method based on lactic dehydrogenase (Duckworth \& Yaphe 1970).

\section{3, 6-ANHYDROGALACTOSE}

The percentage of 3, 6-anhydrogalactose (3, 6-AG) was determined by the resorcinol-acetal method (Yaphe \& Arsenault 1965), using D-fructose as standard. Absorbance was read spectrophotometrically at $555 \mathrm{~nm}$.

\section{Preparation of agarose by adsorption (removal of SULPHUR)}

One hundred grams of agar were suspended in $5 \mathrm{~L}$ of 0.02M EDTA, then stirred for 2 days, and followed by filtration through nylon cloth. Afterwards, particles were re-suspended in $5 \mathrm{~L}$ of $0.01 \mathrm{M}$ EDTA and EDTA was removed by filtration and washing with deionized water for $1 \mathrm{~h}$ (3 times subsequent). The agar particles were easily dried with acetone. Solution of $1.5 \%(\mathrm{w} / \mathrm{v})$ was prepared with the aid of a boiling water bath. When the solution 
was completely clear (1/4 vol), $\mathrm{Al}(\mathrm{OH})_{3}$-gel containing $4 \% \mathrm{AL}_{2} \mathrm{O}_{3}$ was added and mixed with the hot agar solution for at least $10 \mathrm{~min}$. The $\mathrm{AL}(\mathrm{OH})_{3}$ - gel was removed from the hot solution by centrifugation $(10 \mathrm{~min}$ at $2500 \mathrm{rpm})$ or by filtration under suction on a preheated Buchner funnel with a piece of nylon under filter paper in order to have an optimal filtrating surface. After gelatinization, the completely clear supernatant was cut into small pieces which were freeze-thawed and washed twice with deionized water. After then, agarose was dried with acetone (Barteling 1969).

\section{IR ANALYSIS OF EXTRACTED AGAR AND AGAROSE}

Infra-Red spectroscopy was recorded to reveal their functional groups on Shimadzu- Pc 8601 FT-IR spectrometer. The samples were analyzed as $\mathrm{KBr}$ pellet. Both extracted agarose and purchased from Sigma Co., (USA) were analyzed comparatively.

\section{The CALORIFIC CONTENT OF EXTRACTED AGAR}

The calorific content of the extracted agar was calculated to evaluate its nutrition value for human being, using the following known conversion values to convert the organic content into calorific values: fats 9.45, carbohydrates 4.10 and protein $5.65 \mathrm{~K} \mathrm{cal} \mathrm{g}^{-1}$ (Brody 1945). The calorific content of Oxoid agar was also calculated for comparison.

\section{Statistical analysis}

The Pearson's correlation coefficient matrix of various chemical and physical properties of agar including agar yield\%, gel strength, gelling and melting temperature, sulphate, pyruvate, 3,6 anhydrogalactose, viscosity and clarity of agar solution was calculated at confidence limit 90\% $(P \geq 0.1)$, using Excel@ program.

\section{Results}

\section{Algal SPECIES COMPOSITION}

The results of the survey comprised a total of 13 algal samples representing 8 species namely: Ulva compressa (Linnaeus) Nees, Ulva fasciata Delile, Ulva lactuca (Linnaeus), Colpomenia sinuosa (Mertens ex Roth) Derbes et Solier, Corallina officinalis Linnaeus, Gelidium crinale (Turner) Gaillon, Pterocladiella capillacea (S.G. Gmelin) Santelices \& Hommersand and Grateloupia doryphora (Montage) M.A. Howe, which is recently introduced to the Egyptian Mediterranean Sea (pers. comm. Nihal Shams El Din) (Table 2).

\section{BaCteria ASSOCIATED WITH ALGAE}

The average of triplicate count of marine bacteria associated with the algal samples collected from each site in the study area was calculated. However, the standard deviation between the 3 replicates of total bacterial count was negligible. P. capillacea collected either from Abu Qir (I) or from Western Harbor (V) recorded the highest associated bacterial counts. However, it was clear that, P. capillacea AQ (I) had the highest bacterial count $\left(10000 \mathrm{cfu} \mathrm{g}^{-1}\right)$, followed by $P$. capillacea WH (V) (8200 $\left.\mathrm{cfu}^{-1}\right)$ and subsequent by $U$. lactuca from Eastern Harbor (III) (7800 $\mathrm{cfu} \mathrm{g}^{-1}$ ). C. officinalis collected from Anfoushy (IV) had (6250 cfu $\mathrm{g}^{-1}$ ), while the count of associated bacteria with $U$. compressa collected from El Dekheila (VI) was (6000 cfu $\left.\mathrm{g}^{-1}\right)$. The count of associated bacteria with the other algal samples ranged from 1200 to $4600 \mathrm{cfu} \mathrm{g}^{-1}$.

Table 2. Occurrence of the different algal species along Alexandria Coastline, during spring (2012) / Ocurrencia de las diferentes especies de algas a lo largo de la costa de Alejandría, durante la primavera (2012)

\begin{tabular}{|c|c|c|c|c|c|c|}
\hline \multirow[b]{2}{*}{ Algal group } & \multicolumn{6}{|c|}{ Sampling sites } \\
\hline & $\begin{array}{c}\mathrm{AQ} \\
\text { (I) }\end{array}$ & $\begin{array}{c}\text { Sil } \\
\text { (II) }\end{array}$ & $\begin{array}{l}\text { EH } \\
\text { (III) }\end{array}$ & $\begin{array}{l}\text { Anf } \\
\text { (IV) }\end{array}$ & $\begin{array}{l}\text { WH } \\
\text { (V) }\end{array}$ & $\begin{array}{c}\text { DK } \\
\text { (VI) }\end{array}$ \\
\hline \multicolumn{7}{|l|}{ Class: Chlorophyceae } \\
\hline \multicolumn{7}{|l|}{ Order: Ulvales } \\
\hline \multicolumn{7}{|l|}{ Family: Ulvaceae } \\
\hline Ulva compressa & - & - & - & + & - & + \\
\hline Ulva fasciata & + & + & - & + & - & - \\
\hline Ulva lactuca & - & - & + & - & + & - \\
\hline \multicolumn{7}{|l|}{ Class: Phaeophyceae } \\
\hline \multicolumn{7}{|l|}{ Order: Scytosiphonales } \\
\hline \multicolumn{7}{|l|}{ Family: Scytosiphonaceae } \\
\hline Colpomenia sinuosa & + & - & - & - & - & - \\
\hline \multicolumn{6}{|l|}{ Class:Rhodophyceae } & \\
\hline \multicolumn{7}{|l|}{ Order: Corallinales } \\
\hline \multicolumn{7}{|l|}{ Family: Corallinaceae } \\
\hline Corallina officinalis & - & - & - & + & - & - \\
\hline \multicolumn{7}{|l|}{ Order: Gelidiales } \\
\hline \multicolumn{7}{|l|}{ Family: Gelidiaceae } \\
\hline Gelidium crinale & - & - & + & - & - & - \\
\hline Pterocladiella capillacea & + & - & - & - & + & - \\
\hline \multicolumn{7}{|l|}{ Order: Halymeniales } \\
\hline Family: Halymeniaceae & & & & & & \\
\hline Grateloupia doryphora & - & - & + & - & - & - \\
\hline $\mathrm{N}^{\circ}$ of samples & 3 & 1 & 3 & 3 & 2 & 1 \\
\hline
\end{tabular}

$\mathrm{AQ}=\mathrm{Abu}-\mathrm{Qir}$ Bay (I), Sil= El-Silsila (II), EH= Eastern Harbor (III), Anf. $=$ El-Anfoushy $(\mathrm{IV}), \mathrm{WH}=$ Western Harbor $(\mathrm{V})$ and $\mathrm{DK}=\mathrm{El}$ Dekheila (VI) 
Table 3. Gram stain and biochemical tests of dominant bacterial isolates associated to algal species / Tinción de Gram y pruebas bioquímicas de bacterias aisladas dominantes asociadas a especies de algas

\begin{tabular}{|c|c|c|c|c|c|c|c|c|c|}
\hline \multirow{2}{*}{ Test } & \multicolumn{9}{|c|}{ Bacterial isolate $^{*}$} \\
\hline & A1 & $\mathrm{A} 2$ & A3 & A4 & A5 & A6 & A7 & A8 & A9 \\
\hline \multicolumn{10}{|c|}{ Morphological and physiological tests } \\
\hline Shape & $\mathrm{R}$ & $\mathrm{R}$ & $\mathrm{R}$ & $\mathrm{R}$ & $\mathrm{R}$ & $\mathrm{R}$ & $\mathrm{R}$ & $\mathrm{R}$ & $\mathrm{R}$ \\
\hline Gram reaction & - & - & - & - & - & - & - & - & + \\
\hline Motility & + & + & - & - & - & - & - & - & - \\
\hline Aerobic growth & $+{ }^{\mathrm{Rs}}$ & $+{ }^{\mathrm{Rs}}$ & $+{ }^{\mathrm{Rs}}$ & $+{ }^{\mathrm{Rs}}$ & $+^{\mathrm{Rs}}$ & $+^{\mathrm{Rs}}$ & $+{ }^{\mathrm{Rs}}$ & $+^{\mathrm{F}}$ & $+^{\mathrm{F}}$ \\
\hline Anaerobic growth & - & - & - & - & - & - & - & + & + \\
\hline Temperature range $\left({ }^{\circ} \mathrm{C}\right)$ & $20-40$ & $30-37$ & $20-37$ & $20-40$ & $20-40$ & $20-40$ & $20-40$ & $20-45$ & $20-45$ \\
\hline $\mathrm{pH}$ & $5-10$ & $6-9$ & $6-9$ & $6-8$ & $5-9$ & $5-9$ & $4-8$ & $5-10$ & $4-10$ \\
\hline $\mathrm{NaCl} \%$ & $1-10$ & $1-7$ & $0-3$ & $0-4$ & $0-6$ & $1-10$ & $0-6$ & $4-10$ & $1-6$ \\
\hline \multicolumn{10}{|l|}{ Biochemical tests } \\
\hline Catalase & + & + & + & + & + & + & + & + & + \\
\hline Oxidase & + & + & - & + & + & + & + & - & + \\
\hline Indole test & - & - & - & - & - & - & - & - & - \\
\hline Methyl red test & - & - & - & - & - & - & - & - & - \\
\hline Voges-Proskauer test & - & - & - & - & - & - & - & + & - \\
\hline ONPG & - & - & - & - & - & - & + & - & - \\
\hline Citrate utilization & + & + & - & + & + & - & + & - & - \\
\hline Nitrate reduction & - & + & - & + & + & - & + & - & + \\
\hline $\mathrm{H}_{2} \mathrm{~S}$ production & - & - & - & - & - & - & + & - & - \\
\hline Urease production & - & + & - & - & - & - & + & - & - \\
\hline Haemolysis & - & + & - & - & - & - & - & - & - \\
\hline Casein hydrolysis & - & - & - & - & - & - & - & - & - \\
\hline Starch hydrolysis & - & - & - & - & - & - & - & + & + \\
\hline Gelatin hydrolysis & - & - & - & - & - & + & + & - & - \\
\hline Tween 20 hydrolysis & - & - & + & - & - & - & - & - & + \\
\hline Tween 80 hydrolysis & - & - & + & - & - & + & & - & + \\
\hline Esculin hydrolysis & - & - & - & - & - & - & + & - & - \\
\hline \multicolumn{10}{|l|}{ Carbohydrates, acid from } \\
\hline Glucose & + & - & - & - & + & + & + & + & + \\
\hline Arabinose & - & - & - & - & - & + & + & - & - \\
\hline Ethanol & - & - & - & - & - & - & - & - & - \\
\hline Fructose & - & - & - & - & - & - & - & - & - \\
\hline Maltose & - & - & - & - & - & - & + & + & - \\
\hline Mannitol & + & - & - & + & + & - & + & + & - \\
\hline Sucrose & - & - & - & - & - & - & + & + & - \\
\hline Xylose & - & - & - & - & - & + & + & - & - \\
\hline Lactose & - & - & - & - & - & - & + & + & - \\
\hline
\end{tabular}

$\mathrm{R}=$ rods, ${ }^{\mathrm{F}}=$ facultative aerobe, ${ }^{\mathrm{Rs}}=$ restrict aerobe, $\mathrm{ONPG}=$ ortho-Nitrophenyl- $\beta$-galactoside, Bacterial isolate ${ }^{*}$ were identified as: $\mathrm{A} 1=$ Alcaligenes sp., $\mathrm{A} 2=$ Bordetella $\mathrm{sp} ., \mathrm{A} 3=$ Acinetobacter $\mathrm{sp} ., \mathrm{A} 4=$ Pseudomonas $\mathrm{sp} .1$, A5 $=$ Pseudomonas sp.2, A6= Pseudomonas sp.3, A7= Flavobacterium sp., A8=Vibrio sp. and A9= Vigribacillus sp.

From data shown in Table 3, the isolate A1 was characterized by rod shaped cells, Gram -ve bacterial strain, motile and capability of growing in aerobic conditions only with temperature ranged from $20-40^{\circ} \mathrm{C}$. The growth was reported in $\mathrm{pH}$ ranging from 5-10 and $\mathrm{NaCl} 1-10 \%$. They were able to produce catalase, oxidase and utilize citrate. It was negative to the other tests. Acid production was detected from glucose and mannitol fermentations only and it was identified at genus level as Alcaligenes sp.

The cells of isolate coded A2 were rod shaped, Gram -ve, motile, restricted aerobe with growth temperature ranging from $30-37^{\circ} \mathrm{C}$ at $\mathrm{pH}$ ranging from $6-9$ and $\mathrm{NaCl}$ $1-7 \%$. It was positive to catalase, oxidase, citrate 
utilization, nitrate reduction, urease and haemolytic ability. It was reported as negative acid production from fermentation of tested sugars. It was identified at genus level as Bordetella sp.

The isolate A3 was rod shaped, Gram -ve, non-motile and restricted aerobe. The growth temperature ranged from 20 to $37^{\circ} \mathrm{C}$ at $\mathrm{pH}$ 6-9 and $\mathrm{NaCl} 0-3 \%$. It was positive to catalase and hydrolyzed tween $20 \& 80$. It was unable to produce acids from the tested sugars. The strain was identified at genus level as Acinetobacter sp.

The isolate A4 was shown as rod shaped cells, Gram -ve, non-motile, restricted aerobe with growth temperature range from $20-40^{\circ} \mathrm{C}$ at $\mathrm{pH} 6-8$ and $\mathrm{NaCl} 0-4 \%$. It was positive to catalase, oxidase, citrate utilization, nitrate reduction, and acid production only from mannitol. The strain was identified at genus level as Pseudomonas sp.1.

The isolate A5 was characterized by rod shaped cells, Gram -ve, non-motile restricted aerobe with growth temperature range from $20-40^{\circ} \mathrm{C}$ at $\mathrm{pH} 5-9$ and $\mathrm{NaCl} 0-6 \%$. It was positive to catalase, oxidase, citrate utilization, nitrate reduction and produced acids from glucose and mannitol fermentations. This strain was identified at genus level as Pseudomonas sp.2.

The cells of isolate coded A6 was characterized by rod shaped cells, Gram -ve, non-motile, restricted aerobe with growth temperature range between $20-40^{\circ} \mathrm{C}$ at $\mathrm{pH} 5-9$ and $\mathrm{NaCl} 1-10 \%$. It was positive to catalase, oxidase, gelatin hydrolysis and tween 80 hydrolysis. It produced acids only from glucose, arabinose and xylose. It was identified at genus level as Pseudomonas sp.3.

The isolate A7 appeared in rod shaped, Gram -ve, nonmotile, restricted aerobe. The growth temperature range was between $20-40^{\circ} \mathrm{C}$ at $\mathrm{pH} 4-8$ and $\mathrm{NaCl} 0-6 \%$. It was positive to catalase, oxidase, ONPG, citrate utilization, nitrate reduction, $\mathrm{H}_{2} \mathrm{~S}$ production, urease production, gelatin hydrolysis and esculin hydrolysis. It produced acids from glucose, arabinose, maltose, mannitol, sucrose, xylose and lactose. It was identified at genus level as Flavobacterium sp.

The isolate coded A8 was rode shaped cells, Gram -ve, non-motile, aerobic strain and facultative anaerobe with growth temperature range between $20-45^{\circ} \mathrm{C}$ at $\mathrm{pH} 5-10$ and $\mathrm{NaCl} 4-10 \%$. It was positive to catalase and VogesProskauer test, starch hydrolysis. It produced acids from glucose, maltose, mannitol, sucrose and lactose. It was identified at genus level as Vibrio sp.

The isolate A9 was characterized by rode shaped cells, Gram +ve, non-motile, aerobe and facultative anaerobe with growth temperature range between $20-45^{\circ} \mathrm{C}$ at $\mathrm{pH} 4-$ 10 and $\mathrm{NaCl} 1-6 \%$. It was positive to catalase, oxidase, nitrate reduction, starch hydrolysis, tween 20 and 80 hydrolysis and acid production from glucose only. It was identified at genus level as Vigribacillus sp.

On the other hand, the hydrolytic enzyme activities of the 9 dominant isolates associated with algal species were estimated. The results represented in Table 4 illustrated that the most superior species had the property to secret a package of degrading enzymes was Vigribacillus sp.,

Table 4. Hydrolytic enzyme activity of dominant bacterial isolates associated with algal species / Actividad de la enzima hidrolítica de las bacterias aisladas dominantes y asociadas con especies de algas

\begin{tabular}{|c|c|c|c|c|c|c|c|c|}
\hline \multirow{2}{*}{$\begin{array}{l}\text { Bacterial } \\
\text { isolate }\end{array}$} & \multicolumn{6}{|c|}{ Enzyme activity (AU) } & \multirow{2}{*}{$\begin{array}{c}\text { Algal } \\
\text { associated }\end{array}$} & \multirow{2}{*}{$\begin{array}{c}\text { Sampling } \\
\text { site }\end{array}$} \\
\hline & $\mathrm{C}^{\text {ase }}$ & $\mathrm{P}^{\text {ase }}$ & $\mathrm{A}^{\text {ase }}$ & $\mathrm{Ag}^{\text {ase }}$ & $\mathrm{Ch}^{\text {ase }}$ & $\mathrm{L}^{\text {ase }}$ & & \\
\hline Alcaligenes sp. & - & - & - & - & 2.7 & - & U. fasciata & Sil. (II) \\
\hline Bordetella sp. & - & - & - & 1.5 & - & - & U. compressa & $\mathrm{DK}(\mathrm{VI})$ \\
\hline Acinetobacter sp. & 1.4 & - & - & 2.0 & - & 2.1 & C. officinalis & Anf. (IV) \\
\hline Pseudomonas sp.1 & - & - & - & 1.6 & - & - & U. lactuca & EH (III) \\
\hline Pseudomonas sp.2 & - & 1.5 & - & 1.2 & - & - & G. crinale & EH (III) \\
\hline Pseudomonas sp.3 & 1.8 & - & - & 1.7 & 1.5 & - & C. sinuosa & AQ (I) \\
\hline Flavobacterium sp. & - & 1.2 & - & 1.5 & - & - & U. compressa & DK (VI) \\
\hline Vibrio sp. & - & - & 1.8 & - & 1.7 & - & P. capillacea & AQ (I) \\
\hline Vigribacillus sp. & 2.2 & 1.8 & 1.6 & 2.5 & 1.2 & 1.7 & P. capillacea & WH (V) \\
\hline
\end{tabular}

$\mathrm{C}^{\text {ase }}=$ cellulase, $\mathrm{P}^{\text {ase }}=$ protease, $\mathrm{A}^{\text {ase }}=$ amylase, $\mathrm{Ch}^{\text {ase }}=$ chitinase and $\mathrm{L}^{\text {ase }}=$ lipase 
which was isolated from $P$. capillacea harvested from Western Harbor (V). Such isolate had the highest absolute activity for cellulase $(\mathrm{AU}=2.2)$, protease $(\mathrm{AU}=1.8)$ and agarase $(\mathrm{AU}=2.5)$. Whereas, it had a moderate absolute activity for amylase $(\mathrm{AU}=1.6)$ and lipase $(\mathrm{AU}=1.7)$ compared to the other producers, Vibrio sp. $(\mathrm{AU}=1.8)$ and A. lwofii ( $\mathrm{AU}=2.1)$, respectively. Moreover, Vigribacillus sp. had the lowest absolute activity for chitinase $(\mathrm{AU}=1.2)$, while higher activity was observed by Pseudomonas sp.3 (AU=1.5) followed by, Vibrio sp. $(\mathrm{AU}=1.7)$, attending a maximum by Alcaligenes $\mathrm{sp}$. (AU= 2.7), where $A U$ is the absolute unit and equals $\pi \mathrm{Y}^{2} / \pi \mathrm{X}^{2}$ where the $(\mathrm{Y})$ is the radius of clearance zone around well, while $(\mathrm{X})$ is the radius of the well itself (El-Masry et al. 2002).

\section{Agar production}

However, the 2 Rhodophytes G. crinale and P. capillacea only can be exploited for agar and agarose production. But due to the scarcity of $G$. crinale and its presence in minor quantities in contrast to the large quantities of $P$. capillacea, the latter species was chosen for the extraction of agar. Large amounts of the alga (about 1.0-1.5 kg) were harvested from the most abundant site (ST. I), washed very carefully, let to be dried on sheets for few days (5-6 days $)$ at room temperature $\left(25^{\circ} \mathrm{C}\right)$ and then was used in dry form.

\section{BIOCHEMICAL, MAJOR AND TRACE ELEMENTS CONTENTS OF EXTRACTED AGAR}

The results of biochemical contents (total carbohydrates, total proteins and total lipids) of $P$. capillacea, extracted agar and Oxoid agar are shown in (Table 5). The total carbohydrates in the alga was $25.2 \%$, whereas it attained in extracted and Oxoid agar (77.3 and 74.6\%), respectively. The total protein content was relatively low in the 3 samples: $P$. capillacea (7.3\%), extracted and Oxoid agar (0.5 and 2.7\%), respectively. The total lipid content was $20.5 \%$ in the alga, whereas it attained in the extracted and Oxoid agar the percentage of 14.0 and $11.7 \%$, respectively.

The concentration of calcium element in the algal sample far exceeded that in extracted agar (33.4 and $6.7 \mathrm{mgg}^{-1}$ ), respectively, whereas, it was undetectable in Oxoid agar. The results for magnesium showed low concentrations in the alga and extracted agar (12.2 and $15.8 \mathrm{mgg}^{-1}$ ), respectively and was undetectable in Oxoid agar. The sodium content was $1.9 \mathrm{mgg}^{-1}$ in the alga, whereas it attained $5.0 \mathrm{mgg}^{-1}$ in the extracted and $4.4 \mathrm{mgg}^{-1}$ in Oxoid agar. The
Table 5. Chemical analysis of P. capillacea, extracted agar and $0 x$ xoid agar / Análisis químico de P. capillacea, agar extraído y Oxoid

\begin{tabular}{lccc}
\hline \multicolumn{1}{c}{ Analysis } & $\begin{array}{c}\text { Pterocladiella } \\
\text { capillacea }\end{array}$ & $\begin{array}{c}\text { Extracted } \\
\text { agar }\end{array}$ & $\begin{array}{c}\text { Oxoid } \\
\text { agar }\end{array}$ \\
\hline Total carbohydrate $(\%)$ & 25.2 & 77.3 & 74.6 \\
Total protein (\%) & 7.3 & 0.5 & 2.7 \\
Total lipids (\%) & 20.5 & 14.0 & 11.7 \\
$\mathrm{Ca}\left(\mathrm{mg} \mathrm{g}^{-1}\right)$ & 33.4 & 6.7 & $\mathrm{~N} . \mathrm{D}$ \\
$\mathrm{Mg}\left(\mathrm{mg} \mathrm{g}^{-1}\right)$ & 12.2 & 15.8 & $\mathrm{~N} . \mathrm{D}$ \\
$\mathrm{Na}\left(\mathrm{mg} \mathrm{g}^{-1}\right)$ & 1.9 & 5.0 & 4.4 \\
$\mathrm{~K}\left(\mathrm{mg} \mathrm{g}^{-1}\right)$ & 0.7 & 1.3 & $\mathrm{~N} . \mathrm{D}$ \\
$\mathrm{Cu}(\mathrm{ppm})$ & 9.1 & 29.5 & 2.7 \\
$\mathrm{Cd}(\mathrm{ppm})$ & 0.9 & 0.9 & 0.7 \\
$\mathrm{~Pb}(\mathrm{ppm})$ & $*$ & 1.5 & 0.5 \\
$\mathrm{Zn}(\mathrm{ppm})$ & 76.5 & 60.3 & 26.2 \\
$\mathrm{Ni}(\mathrm{ppm})$ & 9.6 & 11.3 & 8.3 \\
$\mathrm{Cr}(\mathrm{ppm})$ & 6.1 & 7.2 & 7.1 \\
$\mathrm{Fe}(\mathrm{ppm})$ & 481.9 & 229.2 & 225.2 \\
$\mathrm{Mn}(\mathrm{ppm})$ & 78.2 & 41.9 & 12.9 \\
$\mathrm{As}(\mathrm{ppm})$ & $*$ & 2.4 & 0.9 \\
$\mathrm{Calorific}$ content & & 126.0 & 120.4 \\
(cal/28g) & 95.2 & & \\
\hline
\end{tabular}

ND means under the detection limit; *Means that not measured

potassium concentration was low in the alga and the extracted agar, whereas it was undetectable in Oxoid agar (Table 5).

Concerning the trace metals, they recorded comparable concentrations in extracted and Oxoid agar; except that of copper, lead, zinc, manganese and arsenic, which exceeded in extracted agar. On the other hand the alga recorded relatively high concentration of zinc $(76.5 \mathrm{ppm})$ and ferrous (481.9 ppm) (Table 5).

\section{The PHYSICAL AND RHEOLOgICAL PROPERTIES OF EXTRACTED AGAR}

As shown in Table 6, the moisture and ash content of extracted agar were higher than Oxoid agar; $(6.8 \pm 0.3$ and $2.2 \pm 0.1 \%)$ for moisture and $(3.8 \pm 3.1$ and $2.2 \pm 2.5 \%)$ for ash, respectively. The $\mathrm{pH}$ of the $1.5 \% \mathrm{w} / \mathrm{v}$ extracted agar solution was alkaline (8.5), whereas the $\mathrm{pH}$ of the Oxoid solution was almost neutral 7.5. The gel strength of extracted agar at different temperatures was lower than that of Oxoid agar, namely: $(608 \pm 30.1$ and $1180 \pm 80.0$ $\left.\mathrm{gcm}^{-2}\right)$ at $25^{\circ} \mathrm{C} ;\left(405.0 \pm 40.0\right.$ and $\left.648.3 \pm 18.9 \mathrm{gcm}^{-2}\right)$ at $85^{\circ} \mathrm{C}$ and $\left(386.7 \pm 15.3\right.$ and $\left.755.0 \pm 40.9 \mathrm{gcm}^{-2}\right)$ at $90^{\circ} \mathrm{C}$, respectively. The gelling temperature of extracted agar was higher than that of Oxoid one $(37.0 \pm 2.0$ and $31.0 \pm$ $0.2^{\circ} \mathrm{C}$ ), respectively. Whereas, the melting temperature of extracted and Oxoid agar showed inverse pattern. The sulfate content of the extracted agar was slightly higher 
than that of Oxoid one $(2.0 \pm 0.2$ and $1.3 \pm 0.2 \%)$, respectively. The same pattern was for and 3, 6 anhydrogalactose $(24.4 \pm 2.7$ and $13.3 \pm 2.3 \%)$, respectively. Whereas, the results of viscosity, clarity and pyruvate content were lower in extracted agar than Oxoid agar.

\section{The CALORIFIC CONTENT OF EXTRACTED AGAR}

The calorific content of the extracted agar was higher than that of Oxoid agar (126.0 and $120.4 \mathrm{cal} /$ ounce), respectively. Whereas, the calorific content of $P$. capillacea was $95.2 \mathrm{cal} /$ ounce, where one ounce equals $28 \mathrm{~g}$ (Table 5).

Table 6. Properties of extracted agar corresponding to Oxoid agar I Propiedades del agar extraído correspondiente al agar Oxoid

\begin{tabular}{lcc}
\hline Property & Extracted agar & Oxoid agar \\
\hline Moisture content $(\%)$ & $6.8 \pm 0.3$ & $2.2 \pm 0.1$ \\
Ash (\%) & $3.8 \pm 3.1$ & $2.2 \pm 2.5$ \\
$\mathrm{pH} 1.5 \%$ & $8.5 \pm 0.0$ & $7.5 \pm 0.0$ \\
Gel strength at $25^{\circ} \mathrm{C}\left(\mathrm{g} \mathrm{cm}^{-2}\right)$ & $608.3 \pm 30.1$ & $1180 \pm 80.0$ \\
Gel strength at $85^{\circ} \mathrm{C}\left(\mathrm{g} \mathrm{cm}^{-2}\right)$ & $405.0 \pm 40.0$ & $648.3 \pm 18.9$ \\
Gel strength at $90^{\circ} \mathrm{C}\left(\mathrm{g} \mathrm{cm}^{-2}\right)$ & $386.7 \pm 15.3$ & $755.0 \pm 40.9$ \\
Gelling temp. $\left({ }^{\circ} \mathrm{C}\right)$ & $37.0 \pm 2.0$ & $31.0 \pm 0.2$ \\
Melting temp. $\left({ }^{\circ} \mathrm{C}\right)$ & $76.0 \pm 1.5$ & $86.8 \pm 3.0$ \\
Viscosity $1.5 \%(\mathrm{cps})$ & $3.9 \pm 0.1$ & $6.5 \pm 0.3$ \\
Clarity (Nepehols) & $60.7 \pm 4.0$ & $81.0 \pm 7.0$ \\
Sulfate \% & $2.0 \pm 0.2$ & $1.3 \pm 0.2$ \\
Pyruvate \% & $8.8 \pm 1.1$ & $14.4 \pm 0.7$ \\
3, 6 anhydrogalactose $\%$ & $24.4 \pm 2.7$ & $13.3 \pm 2.3$ \\
\hline
\end{tabular}

The properties of native agar extracted from Pterocladiella capillacea in this study are compared with native agar from the same alga of previous studies, which showed great differences (Table 7).

\section{IR OF AGAR}

Both types of agar were examined by IR spectrophotometer. The results of the agar spectrum (Fig. 2) showed a strong absorption band in Oxoid agar at 3471.98-3475.84 due to the stretching vibration of $\gamma(\mathrm{o}-$ $\mathrm{H})$, a band at 1068.49 36-anhydro-galactose bridge vibration (typical agar peak), a band at 1401.19 peak with unknown meaning and band at 1644.20 (amine function deformation vibrations). On the other hand, the extracted agar showed a band at 1060.78 indicating the presence of ester sulphate link vibration. The first band indicated that methylated group; complete methylation was appeared at C6 position of Dglactopyranosyl units by the absence of C6 nonmethylated D-glactopyranorgl single at 652. This indicated that the agar extracted from $P$. capillacea is highly methylated polysaccharide resulting in high gellation.

\section{IR OF AGAROSE}

The result of agarose from $P$. capillacea (Fig. 3) revealed the presence of a band at 3475.84 which is related to $\mathrm{OH}-$ stretching of hydroxyl group, a band at $1647.26 \mathrm{~cm}^{-1}$ assigned to an asymmetric stretching vibration of $\mathrm{O}-\mathrm{C}-\mathrm{O}$ and the characteristic absorption bands of the vibrations of sulphate groups at 1410.01, 1080.17 which is an important criterion in determination the quality of agarose.

Table 7. Comparison of properties of extracted agar with previous studies from P. capillacea / Comparación de las propiedades de agar extraído con estudios previos de P. capillacea

\begin{tabular}{|c|c|c|c|c|c|c|c|c|c|}
\hline Locality and reference & $\begin{array}{l}\text { Yield } \\
\%\end{array}$ & $\begin{array}{c}\text { Gel } \\
\text { strength } \\
\left(\mathrm{gcm}^{-2}\right)\end{array}$ & $\begin{array}{l}\text { Gelling } \\
\mathrm{T}\left({ }^{\circ} \mathrm{C}\right)\end{array}$ & $\begin{array}{l}\text { Melting } \\
\mathrm{T}\left({ }^{\circ} \mathrm{C}\right)\end{array}$ & $\begin{array}{l}\text { Viscosity } \\
\text { (cps) }\end{array}$ & Clarity & $\begin{array}{l}\text { Sulphate } \\
\%\end{array}$ & $\begin{array}{c}\text { Pyruvate } \\
\%\end{array}$ & $\begin{array}{c}3.6 \\
\text { Anhydro } \\
\%\end{array}$ \\
\hline Egypt, Present study & 12 & 608.3 & 37.0 & 76.0 & 3.9 & 60.7 & 2.0 & 8.8 & 24.4 \\
\hline $\begin{array}{l}\text { Egypt, Rao \& Bekheet } \\
\text { (1976) }\end{array}$ & 14.0 & 725.0 & - & - & - & - & - & - & - \\
\hline $\begin{array}{l}\text { Cote \& Hanisak (1986), } \\
\text { Florida }\end{array}$ & $33-41$ & $110-190$ & $41-45$ & $82-85$ & - & - & $1.8-2.2$ & - & - \\
\hline $\begin{array}{l}\text { Venezuela, Lemus et al. } \\
\text { (1991) }\end{array}$ & 32.1 & 735.3 & 35.5 & 91.5 & - & - & 3.7 & 0.0 & 33.9 \\
\hline $\begin{array}{l}\text { Agaete, Spain, Freile- } \\
\text { Pelegrin et al. (1996) }\end{array}$ & $15-29.5$ & $813-1428$ & $34.6-36.3$ & $88.9-95.5$ & - & - & $2.12-3.43$ & $0.14-0.47$ & - \\
\hline $\begin{array}{l}\text { Bocabarranco, Spain, } \\
\text { Freile-Pelegrin et al. } \\
\text { (1996) }\end{array}$ & $16.7-29.8$ & $912-1354$ & $34.4-36.9$ & $86.9-94.9$ & - & - & $1.9-3.1$ & $0.1-0.5$ & - \\
\hline
\end{tabular}




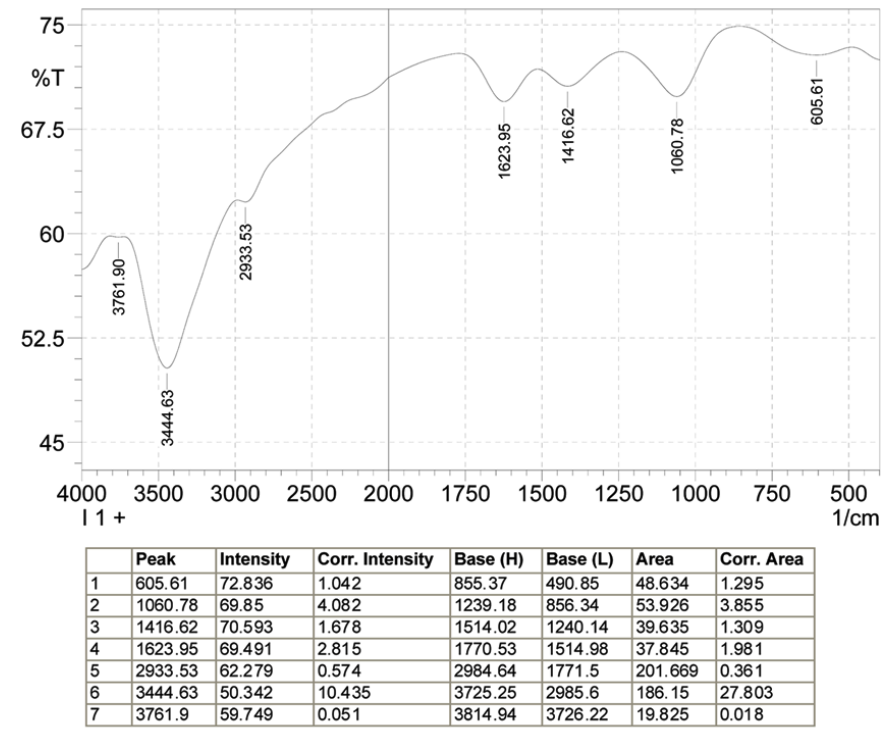

Extracted agar

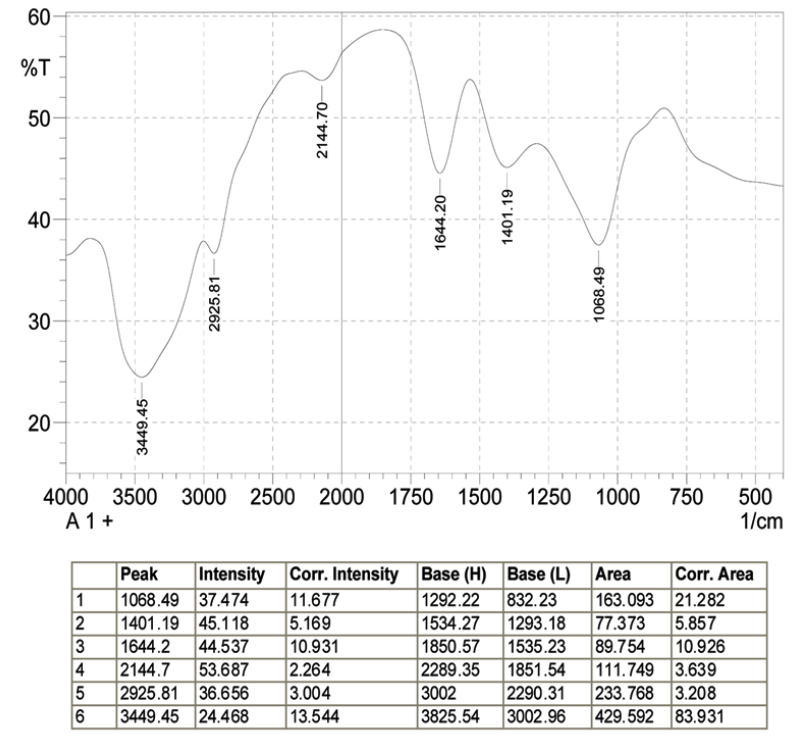

Oxoid agar

Figure 2. FIR profile analysis for both extracted agar and Oxoid agar / FTIR análisis del perfil tanto para el agar extraído y Oxoid

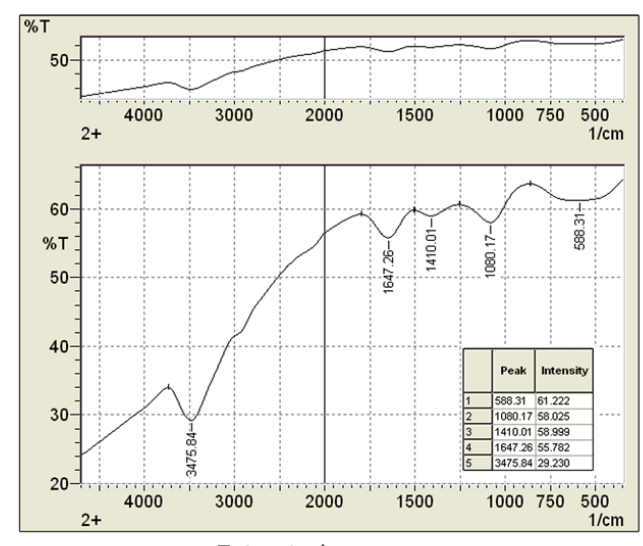

Extracted agarose

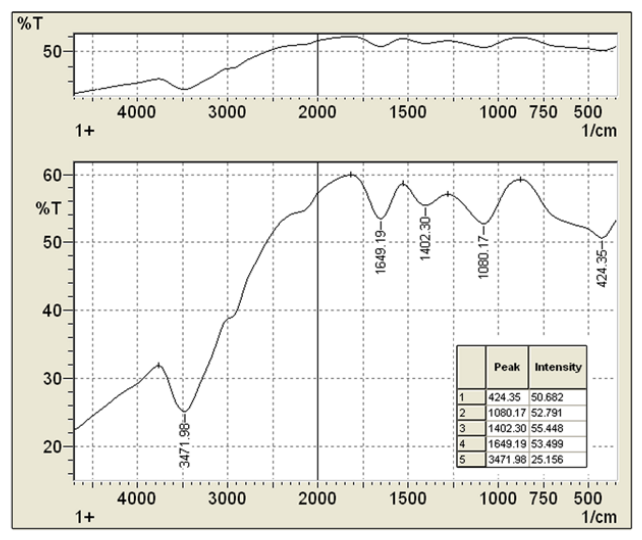

Sigma agarose

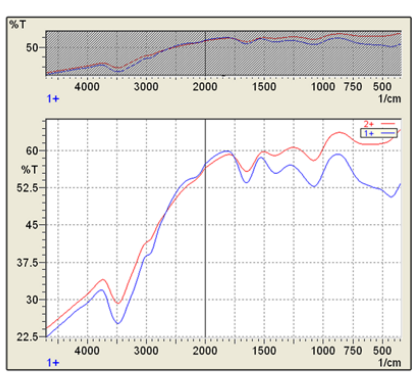

Both agarose

Figure 3. FTIR profile analysis for both extracted agarose and Sigma agarose / FTIR análisis del perfil tanto para agarosa extraída y Sigma

\section{Discussion}

Although the ecological relevance of most bacterial associates on or within macroalgae remains unclear, a number of beneficial and detrimental functions have been postulated for particular bacterial species (Goecke et al. 2010). However, Chan \& McManus (1969) reported that the number of seaweed-associated bacteria exceeds those in the surrounding seawater by 100-10000 times. Also, Largo et al. (1997) found that total viable count reached up to $10^{7}$ bacterial cells per gram dry algal weight using the agar spread plate method, a number that even increases by 2 orders of magnitude when applying direct enumeration techniques.

Many bacteria growing on seaweed surfaces are able to enzymatically decompose algal cell wall, making them key players in biotransformation and nutrient recycling in the oceans (Goecke et al. 2010). Also, beneficial bacterial-macroalgal interactions are based on the bacterial capacity to mineralize algal organic substrates and 
subsequently supply the seaweed host with carbon dioxide, minerals, vitamins, and growth factors (Singh et al. 2011).

Herein, the dominant bacterial isolates detected in the association with the different algal samples were identified at genus level as; Alcaligenes sp., Bordetella sp., Acinetobacter sp., Pseudomonas sp.1, Pseudomonas sp.2, Pseudomonas sp.3, Flavobacterium sp., Vibrio sp. and Vigribacillus sp. As well as, the most superior isolate able to secrete a package of degrading enzymes was Vigribacillus $\mathrm{sp}$. isolated from $P$. capillacea harvested from Egyptian Western Harbor. However, Goecke et al. (2010) mentioned that the algal cell wall degrading bacteria mainly belong to the Alphaproteobacteria, Gammaproteobacteria, and the CFB group. Especially Alteromonas, Flavobacterium, Pseudoalteromonas, Pseudomonas, Vibrio, and Zobellia species possess sugar-degrading enzymes like agarases, carrageenases, and alginate lyases (for an overview of macroalgal cell wall-degrading bacteria).

Currently, the species $P$. capillacea collected in the present study from Abu-Qir Bay appeared to be a rich source of carbohydrates $(25.2 \%)$, lipids $(20.5 \%)$, protein (7.3\%) and minerals such as $\mathrm{Ca}\left(33.4 \mathrm{mg} \mathrm{g}^{-1}\right), \mathrm{Mg}(12.2 \mathrm{mg}$ $\left.\mathrm{g}^{-1}\right), \mathrm{Na}\left(1.9 \mathrm{mg} \mathrm{g}^{-1}\right), \mathrm{K}\left(0.7 \mathrm{mg} \mathrm{g}^{-1}\right), \mathrm{Cu}$ (9.1 ppm), Zn (76.5 ppm), Fe (481.9 ppm) and Mn (78.2 ppm), which were more or less comparable to the results of Pterocladiella collected from Alexandria coast (Abdallah 2008) except remarkably higher $\mathrm{Mg}$ content $\left(170.69 \mathrm{mg} \mathrm{g}^{-1}\right)$ in the previous study. However, Abdallah (2008) and El-Said \& El-Sikaily (2013) recommended this species for human food consumption. In this trend, Sebaaly et al. (2012) confirmed the potential use of the red alga Pterocladiella in the food industry as a source of highly nutritious ingredients. On the other hand, this species contains polysaccharidetype compounds such as sulfated galactans and carageenans that exhibit a broad spectrum of biological activity.

However, few literatures were available on extraction of agar from this alga. The agar isolated from $P$. capillacea in this study recorded a yield of $12 \%$ dry weight of the alga. This was comparable to the results of Rao \& Bekheet (1976). But lower than the results of Cote \& Hanisak (1986), Lemus et al. (1991). On the other hand, Freile-Pelegrin et al. (1996) recorded wide range of agar yield during different seasons and from different regions. Meanwhile, the present yield was found to be considerably lower than that reported for almost other agarophytes (Kaliaperumal et al. 1992, Freile-Pelegrin \& Murano 2005, Arvizu-Higuera et al. 2008). It was reported that agar yield depends on gender and species of agarophytes, which have their specific genetic characteristics (Armisén \& Galatas 1987). On the other hand, the variation in agar yield depends on the environmental conditions, the geographical distribution, the season of harvesting the alga (Freile-Pelegrin et al. 1996) and different life phases of algae (Whyte et al. 1981).

One of the most important factors that affected the yield of agar is the extraction method, which includes the pretreatment of the agarophytes with alkali or without treatment, concentration of the alkali, the nature of the alga (grounded or not) (Rao \& Bekheet 1976, Villanueva et al. 2010), temperature and duration of extraction (Pereira-Pacheco et al. 2007). According to Montano et al. (1999) the low yield extraction of our native agar from the alga might be due to a high content of non-gelling water-soluble agar and leaching out during the extraction process. In this trend, Villanueva et al. (2010) reported that the agar extracted without alkali in the pretreatment solution makes the algal thallus relatively softer than those treated with alkali after the pretreatment step. Alkali could have a stiffening effect on the thallus, thereby preventing leaching out of agar from the seaweed during the pretreatment, but in low concentrations (Rath \& Adhikary 2004). These findings may explain our results.

However, agar is built on a disaccharide-repeating unit of 3-linked D-galactose and 4-linked 3, 6-anhydro-Lgalactose $(3,6-\mathrm{AG})$ residues, with possible occurrence of sulphate, methoxyl, and/or pyruvate substituents at various positions in the polysaccharide chain (Rees 1969). The type, pattern, and degree of substitution are useful in classifying agar properties (Villanueva et al. 2010).

Gel strength of agar is considered as an important quality parameter distinguishing between the strong brittle gels used in bacteriological and biomedical applications, and soft elastic gels used in the food industry (Yaphe \& Duckworth 1972). The gel strength of extracted agar was more or less comparable to gel strength of native agar of the same alga (Rao \& Bekheet 1976, Lemus et al. 1991), higher than that of Cote \& Hanisak (1986) and lower than that of Freile-Pelegrin et al. (1996). On the other hand, gel strength of $P$. capillacea was higher than the remarkably low gel strength recorded in Gracilaria corticata $(12.0$ $\mathrm{gcm}^{-2}$ ) (Kaliaperumal et al. 1992) and that of other native agarophytes (Lemus et al. 1991, Freile-Pelegrin \& Murano 2005, Arvizu-Higuera et al. 2008 \& Villanueva et al. 2010) except that of Gracilaria floridanum $\left(1030.0 \mathrm{~g} \mathrm{~cm}^{-2}\right)$ (Lemus et al. 1991) and Gracilaria blodgetii $\left(750.0 \mathrm{~g} \mathrm{~cm}^{-2}\right)$ (Freile-Pelegrin \& Murano 2005). This result was associated 
with low sulphate percent and high 3, 6-anhydrogalactose percent, which are considered as the gel regulating factors (Asare 1980). In this trend, Rath \& Adhikary (2004) reported that higher contents of 3,6-AG and lower levels of sulphation resulting in strong gels. However, Armisén \& Galatas (1987) found that the common percentage of sulphate content is below $0.15 \%$ but sometimes higher content $(5-8 \%)$ are registered. In the present study, these parameters were not limiting factors for gel strength and were insignificantly correlated with it. Our findings agreed with Yaphe \& Duckworth (1972), and Freile-Pelegrin et al. (1996).

In fact, many authors reported that gel strength increases by alkali pretreatment, giving higher values than that of native agar. This is attributed to that during alkali treatment the L-galactose 6-sulfate can be converted to 3,6-anhydrogalactose (Villanueva et al. 2010). Furthermore, the variability in agar gel quality in the same species and/or in different agarophytes may be attributed to the different geographical origin and environmental conditions where the seaweeds grow, which can partly influence the quality of the agar from the alga (Rebello et al. 1997). On the other hand, Armisén \& Galatas (1987) reported that the harvesting period of the algae is of great importance for the production of agarobioses (types of agar), and they considered that summer season is the most suitable as agar plants matured gradually through this season, which was the reason for harvesting the plant during this season in the present study.

However, Armisén (1995) set a value for different use of agar according to the gel strength. Agar with gel strengths $<600 \mathrm{gcm}^{-2}$ can be used for traditional domestic use, whereas that with gel strength $>600 \mathrm{gcm}^{-2}$ can be used as industrial food-grade type. On the other hand, agar with gel strength $>700 \mathrm{gcm}^{-2}$ can be used for bacteriological purposes (Armisén \& Galatas 1987). Accordingly, our extracted agar can be used in food industries.

The gelling temperature of extracted agar was comparable to that of Lemus et al. (1991) and FreilePelegrin et al. (1996) but lower than that of Cote \& Hanisak (1986). Whereas, the gelling temperature of our agar was more or less comparable to that of other agarophytes (Lemus et al. 1991, Freile-Pelegrin \& Murano 2005, Prasad et al. 2007), lower than that of Kaliaperumal et al. (1992) and Praiboon et al. (2006) and higher than that of ArvizuHiguera et al. (2008) and Villanueva et al. (2010).
On the other hand melting temperature of extracted agar was lower than all the results of agar recorded in the previous studies (Cote \& Hanisak 1986, Lemus et al. 1991, Freile-Pelegrin et al. 1996). Whereas, the melting temperature of our agar was lower than of the other agarophytes in the previous studies (Lemus et al. 1991, Prasad et al. 2007) and higher than that of Arvizu-Higuera et al.(2008) and Villanueva et al. (2010).

According to Armisén \& Galatas (1987), gel temperature is an indicator to identify the agarophyte used to produce an agar. Armisén (1995) reported that the typical gel temperature of agar extracted from Pterocladiella spp. ranging from $\left(33-35^{\circ} \mathrm{C}\right)$, which differed in the other agarophytes. Our results agreed with these findings.

It was reported that the higher gelling temperature is indicative of higher methoxyl content in the polysaccharide chain constituting the agar (Guiseley 1970). Similarly, higher melting temperature is an indicator of greater molecular weight and size of the agar polymer (Selby \& Wynne 1973). The longer polymers might be more capable of interacting with each other and forming a greater 3-dimensional lattice between water and the gel helices. On the other hand, Cote \& Hanisak (1986) showed that increasing amounts of 36-AG and decreasing amounts of sulphate in agar lead to higher melting temperature. However, the amounts of 36-AG in our agar was lower than all the agarophytes of the previous studies (Lemus et al. 1991, Freile-Pelegrin \& Murano 2005, Prasad et al. 2007, Villanueva et al. 2010), and higher than that of Rath \& Adhikary (2004), who recorded a range from 16.0 to $22.2 \%$. In agreement with Freile-Pelegrin \& Murano (2005), a strong positive correlation was found between gelling and melting temperature $(\mathrm{r}=1.00 ; P<0.1)$. Moreover, both variables were correlated negatively with gel strength ( $\mathrm{r}$ for both $=-0.99 ; P<0.1$ ). This result contrasted with that of Freile-Pelegrin \& Murano (2005). However, any correlation between gel strength and gelling and melting temperature could in part be explained by the methoxyl substitutions at various positions in the agar molecule (Yaphe \& Duckworth 1972).

In fact, the difference between the gelling and melting temperatures known as hysteresis is a striking factor, which controls the agar gel strength. Armisén \& Galatas (1987) recorded a gel hysteresis of $45^{\circ} \mathrm{C}$ in many agarophytes, which is considered the most common. This property depends on the presence of agarobioses originally in the agarophyte from where the agar extracted (Armisén \& Galatas 1987), which may explain the difference in gel hysteresis in the present study $\left(39^{\circ} \mathrm{C}\right)$ 
and the previous ones. Currently, high gelling hysteresis is required to improve gel strength (Armisén \& Galatas 1987).

The pyruvate content in the present study was remarkably higher compared with the extracted agar from the same alga (Lemus et al. 1991, Freile-Pelegrin et al. 1996). Also pyruvate content of our agar far exceeded that from other agarophytes; Gracilaria floridanum and G. serulatum (0.2 and 0.4\%), respectively (Lemus et al. 1991). According to Freile-Pelegrin et al. (1996), the high pyruvate content decreases the gel strength, which may explain the lower gel strength of our agar in comparison with the other literatures (Lemus et al. 1991, Freile-Pelegrin et al. 1996). However, food grade agars are reported to be containing more agarose molecules that are substituted with sulfate or pyruvate (Duckworth \& Yaphe 1971).

Higher viscosity correspondence with low yield of agar is due to the difficulty of filtration of the gel solution (Istini et al. 1994). There was no available literature of viscosity in P. capillacea but Praiboon et al. (2006) recorded values of viscosity in Gracilaria fisheri and G. edulis (18.4 and 22.1 cps), respectively, which were higher than that of the present study. On the other hand, Prasad et al. (2007) recorded wide range of viscosity with different values in Glediella acerosa according to the geographical distribution and the harvesting period of the agarophyte $(15.0-67.0 \mathrm{cps})$. These factors in addition to the extraction conditions and duration time of extraction process, measurement conditions of viscosity such as temperature of the gel solution, concentration of agar and (spindle and rpm) (Pereira-Pacheco et al. 2007), may explain the difference of these results than our result. In fact, Prasad et al. (2007) reported that agar samples having low gel strength and high visco-elasticity are preferred for food applications.

Another feature of an agar gel is the clarity, which is generally required in commercial agar used for various purposes, but is omitted from most of literatures. In fact, the only available literature was that of Rao \& Bekheet (1976), where they only described the gel solution from the point of its color, transparency and presence or absence of insoluble particles. Thus, it was difficult to compare the present results with this descriptive study. On the other hand, Praiboon et al. (2006) approved that good clarity is required to have better rheological properties of agar but they didn't measure this parameter.
The use of infrared spectroscopy for the structural analysis of agars is well established (Rochas et al. 1986). The FTIR spectrum of the present phycocolloid sample showed the main characteristic absorption bands of agar (Murano 1995), thus confirming its identity as agar.

On the other hand, from the IR spectrometer we found that the spectrum of agar and agarose were not the same. However, agar is an intermediate form of low molecular weight and quite sulphated which is secreted in Golgi apparatus of the cell and once deposited in the cell wall and polymerizes and desulfates enzymatically being converted mostly in agarose that gives the agar its gelling power (Armisén \& Galatas 1987). Thus, agarose contains low sulphate value and high 3,6-anhydrogalactose. Rao \& Bekheet (1976) reported that low ash and sulphate contents and high gel strength lead to obtain agar richer in agarose of high quality. The acceptable value for sulphate content is $0.7 \%$ (Guiseley \& Renn 1975).

As extracted agar can be potentially used in different purposes, including food for human being, determination of heavy metals in the extract was imperative. However, there are no available literatures that give information about concentrations of these elements in their produced agar.

Heavy metals can be toxic for humans when they are not metabolized by the body and accumulate in the soft tissues. It is noteworthy to mention that consumption of food with a high heavy metal concentration can cause acute or chronic poisoning, which can result in damaged or reduced mental and central nervous function as well as damage to blood composition, lungs, and other vital organs. Long-term exposure to heavy metals may result in slowly progressing physical, muscular, and neurological degenerative conditions as well as cancer (Ducos et al. 2010).

The German Institute for Standardization (DIN 2009) ${ }^{1}$ enforces the DIN EN 15763 norm for the quantification of some heavy metals in foodstuffs such as Arsenic content ranging from 0.06 to $21.5 \mathrm{ppm}$ dry weight, Cadmium (0.03$28.3 \mathrm{ppm})$ and Lead (0.01-2.4 ppm). Accordingly, extracted agar recorded lower values than the permissible range of the concentration of these metals. Also this seaweed species was of high quality and safety and might be used in the field of nutrition.

On the other hand, no available literatures that gives information about nutrition value of their extracted agar from different red algal species. According to Chew $(2013)^{2}$, 1ounce serving size ( $28 \mathrm{~g}$ ) of agar contains $0.9 \mathrm{~g}$ of total fat,

${ }^{1}$ German Institute for Standardization (DIN). 2009. Foodstuffs - determination of trace elements - determination of tin by inductively coupled plasma mass spectrometry (ICP-M S) after pressure digestion; German version EN 15763:2009. DIN. Berlin 
$22.93 \mathrm{~g}$ of carbohydrate, $1.76 \mathrm{~g}$ of protein and 87 calories. The mineral content in this serving size includes $177.19 \mathrm{mg}$ of calcium, $318.84 \mathrm{mg}$ potassium, $6.07 \mathrm{mg}$ iron and $28.92 \mathrm{mg}$ of sodium. Thus, 1- ounce serving size of our agar contains $3.92 \mathrm{~g}$ of total fat, $21.64 \mathrm{~g}$ of carbohydrate, $0.14 \mathrm{~g}$ of protein and 126 calories. Whereas, the mineral content of our agar includes $187.6 \mathrm{mg}$ of calcium, $36.4 \mathrm{mg}$ of potassium, $6.3 \mathrm{mg}$ iron and $140.0 \mathrm{mg}$ of sodium. However, these values corresponded with that of Oxoid agar, except higher values of calcium and sodium than that in Oxoid agar and much lower values of protein and potassium than reported by Chew $(2013)^{2}$. Accordingly, extracted agar can be used in food products for human being.

In conclusion, epiphytic bacteria were associating with algae and hence degrading algal cell walls successfully by secreting package of hydrolytic enzymes. Pterocladiella have high nutritional value and can be considered as a major resource for economic and industrial development as well as a source of therapeutic and phycolloidal substances like agar. The extracted agar might be used in the field of nutrition, especially that it recorded lower values of trace metals than the permissible dose. Finally, the improvement of rheological properties of agar gel is highly required such as improvement of agar gel strength, gelling and melting temperature and hysteresis, by applying suitable extraction methods to reach the optimum conditions to obtain higher agar quality.

\section{ACKNOWLEDGMENTS}

The research leading to these results has supported by the research plan through the strategy of Marine Environment Division (2012-2014), National Institute of Oceanography and Fisheries (NIOF), Egypt.

\section{LITERATURE CITED}

Abdallah MAM. 2008. Chemical composition, mineral content and heavy metals of some marine seaweeds from Alexandria Coast, Egypt: potential uses. Egyptian Journal of Aquatic Research 34(2): 84-94.

Aleem AA. 1993. The marine algae of Alexandria, Egypt, 139 pp. Privately published, Alexandria.

APHA. 1975. Standard methods for the examination of water and waste water by American Public Health Association, 1193 pp. APHA, New York

Armisén NR \& F Galatas. 1987. Production properties and uses of agar. Production and utilization of products from commercial seaweed. FAO Fisheries Technical Paper 288: 1-57.
Armisén R. 1995. World-wide use and importance of Gracilaria. Journal of Applied Phycology 7: 231-243.

Armstrong E, L Yan, KG Boyd, PC Wright \& JG Burgess. 2001. The symbiotic role of marine microbes on living surfaces. Hydrobiologia 461: 37-40.

Arvizu-Higuera DL, YE Rodríguez-Montesinos, JI MurilloÁlvarez, M Mauricio Muñoz-Ochoa \& G HernándezCarmona. 2008. Effect of alkali treatment time and extraction time on agar from Gracilaria vermiculophylla. Journal of Applied Phycology 20: 5155-5119.

Asare SO. 1980. Seasonal changes in sulphate and 3,6anhydrogalactose content of phycocolloids from two red algae. Botanica Marina 23: 595-598.

Barteling SJ. 1969. A simple method for the preparation of agarose. Clinical Chemistry 15(10): 1002-1006.

Bligh EG \& WM Dyer. 1959. Rapid method for lipid extraction. Canadian Journal of Biochemistry Physiology 35: 911-915.

Braune W. 2008. Meeresalgen. Ein Farbbildführer zu verbereiten Grün-, 596 pp Braun- und Rotalgen der Weltmeere Gantner Verlag Ruggell.

Brody S. 1945. Bioenergetics and growth with special reference to the energetic efficiency complex in domestic animals. Reinhold, New York, 403 pp.

Chan ECS \& EA McManus. 1969. Distribution, characterization, and nutrition of marine microorganisms from the algae Polysiphonia lanosa and Ascophyllum nodosum. Canadian Journal of Microbiology 15:409-420.

Cheesbrough M. 1985. Medical laboratory manual for tropical countries 2:160-174. Cambridge, UK: ELBS, Tropical Health Technology Publications and Butterworth-Heinemann

Cote GL \& MD Hanisak. 1986. Production and properties of native agars from Gracilaria tikvahiae and other red algae. Botanica Marina 29: 359-366.

Cowan ST \& AR Steel. 1993. Cowan and steel's manual for the identification of medical bacteria, 352 pp. Cambridge University Press, Cambridge.

Duckworth M \& W Yaphe. 1970. Definitive assay for pyruvic acid in agar and other algal polysaccharides. Chemistry and Industry London 23: 747-748.

Duckworth M\& W Yaphe. 1971. The structure of agar. Part 1: Fractionation of a complex mixture of polysaccharides. Carbohydrates Research 16: 189-197.

Ducos SM, M Hamester \& MM Godula. 2010. ICP-MS for detecting heavy metals in foodstuffs. Food Quality \& Safety, February <www.foodquality.com/details/article/809781/ICP-MS〉.

El-Masry MH, AI Khalil, MS Hassouna \& HAH Ibrahim. 2002. In situ and in vitro suppressive effect of agricultural composts and their water extracts on some phytopathogenic fungi. World Journal of Microbiology and Biotechnology 18: $551-558$ 
El-Said GF \& A El-Sikaily. 2013. Chemical composition of some seaweed from Mediterranean Sea coast, Egypt. Environmental Monitoring and Assessment 185: 6089-6099.

Freile-Pelegrin Y, D Robledo, R Armisn \& G Garcia-Reina. 1996. Seasonal changes in agar characteristics of two populations of Pterocladia capilacea in Gran Canaria, Spain. Journal of Applied Phycology 8: 239-246.

Freile-Pelegrin Y \& E Murano. 2005. Agars from three species of Gracilaria (Rhodophyta) from Yucatan Peninsula. Journal of Bioresource Technology 96: 295-302.

Glicksman M. 1983. Red seaweed extracts (agar, carrageenans, furcellaran). In: Glicksman M (ed). Food hydrocolloids, pp. 73-113. CRC Press, Boca Raton.

Goecke F, A Labes, J Wiese \& JF Imhoff. 2010. Chemical interactions between marine macroalgae and bacteria. Marine Ecology Progress Series 409: 267-299.

Guiseley KB. 1970. The relationship between methoxyl content and gelling temperature of agarose. Journal of Carbohydrates Research 13: 247-256.

Guiseley KB \& DW Renn. 1975. Agarose: purification properties and biomedical application. 1975 pp. Marine Colloids Division, FMC Corporation Rockland.

Haritonidis S, HJ Jäger \& HO Schwantes. 1983. Accumulation of cadmium, zinc, copper, and lead by marine macrophyceae under culture conditions. Angewandte Botanik 57: 311-330.

Istini S, M Ohno \& K Kusunose. 1994. Method of analysis for agar, carrageenan and alginate in seaweed. Bulletin of Marine Science Fishery, Kochi University 14: 49-55.

Kaliaperumal N, S Kalimuthu \& JR Ramalingam. 1992. Studies on the agar content in Gracilaria arcuata var. arcuata and G. corticata var. cylindrica. Seaweed Research Utilization 15: 191-195.

Lachnit T, M Blumel, JF Imhoff \& M Wahl. 2009. Specic epibacterial communities on macroalgae: phylogeny matters more than habitat. Aquatic Biology 5: 181-186.

Lachnit T, M Wahl \& T Harder. 2010. Isolated thallusassociated compounds from the macroalga Fucus vesiculosus mediate bacterial surface colonization in the eld similar to that on the natural alga. Biofouling 26: 247 255.

Largo DB, K Fukami, M Adachi \& T Nishijima. 1997. Direct enumeration of bacteria from macroalgae by epifluorescence microscopy as applied to the fleshy red algae Kappaphycus alvarezii and Gracilaria spp. (Rhodophyta). Journal of Phycology 33: 554-557.

Lemus A, K Bird, DF Kapraun \& F Koehn. 1991. Agar yield, quality and standing crop biomass of Gelidium floridanum and Pterocladia capillacea in Venezuela. Food Hydrocolloids 5: 469-479.
Mabeau S \& J Fleurence. 1993. Seaweed in food products: biochemical and nutritional aspects. Trends Food Science and Technology 4: 103-107.

MacArtain P, GIR Christopher, M Brooks, R Campbell \& IR Rowland. 2007. Nutritional value of edible seaweeds. Nutrition Reviews 65: 535-543.

Mohamed LA \& A Khaled. 2005. Comparative study of heavy metal distribution in some coastal seaweeds of Alexandria, Egypt. Journal of Chemistry and Ecology 21:181-189.

Montano NE, RD Villanueva \& JB Romero. 1999. Chemical characteristics and gelling properties of agar from two Philippine Gracilaria spp. (Gracilaria, Rhodophyta). Journal of Applied Phycology 11: 27-34.

Murano E. 1995. Chemical structure and quality of agars from Gracilaria. Journal of Applied Phycology 7: 245-254.

Nasr AH, AF Mohsen \& IA Bekheet. 1966. Effect of salinity and temperature variations on Pterocladia capillacea. Hydrobiologia 27: 395-400.

Pereira-Pacheco F, D Robledo, L Rodríguez-Carvaja \& Y Freile-Pelegrín. 2007. Optimization of native agar extraction from Hydropuntia cornea from Yucatán, México. Bioresource Technology 98: 1278-1284.

Praiboon J, A Chirapart, Y Akakabe, O Bhumibhamond \& T Kajiwarac. 2006. Physical and chemical characterization of agar polysaccharides extracted from the Thai and Japanese species of Gracilaria. Science Asia 32 (Suppl) 11-17.

Prasad K, AK Siddhanta, M Ganesan, BK Ramavat, B Jha \& PK Ghosh. 2007. Agars of Gelidiella acerosa of west and southeast coasts of India. Bioresource Technology 98:1907-1915.

Rao AV \& IA Bekheet. 1976. Preparation of Agar-Agar from the red seaweed Pterocladia capillacea off the Coast of Alexandria, Egypt. Journal of Applied Environmental Microbiology 32(4): 479-482.

Rath J \& SP Adhikary. 2004. Effect of alkali treatment on the yield and quality of agar from red alga Gracilaria verrucosa (Rhodophyta, Gracilariales) occurring at different salinity gradient of Chilika lake. Indian Journal Marine Sciences 33(2): 202-205.

Raymont JEG, J Austin \& E Linford. 1964. Biochemical studies on marine zooplankton. I. The biochemical composition of Neomysis integer. Journal Conseil Permanent International pour l'Exploration de la Mer 28: 354-363.

Rebello J, M Ohno, H Ukeda \& M Sawamura. 1997. Agar quality of commercial agarophytes from different geographical origins: Physical and rheological properties. Journal of Applied Phycology 8: 517-521.

Rees DA. 1969. Structure, conformation and mechanism in the formation of polysaccharide gels and networks. Advances in Carbohydrate Chemistry and Biochemistry 24: 267-332. 
Rochas C, M Lahaye \& W Yaphe. 1986. Sulphate content of carrageenan and agar determined by infrared spectroscopy. Botanica Marina 29: 335-340.

Sebaaly C, N Karaki, N Chahine, A Evidente, A Yassine, J Habib \& H Kanaan. 2012. Polysaccharides of the red algae 'Pterocladia' growing on the Lebanese coast: Isolation, structural features with antioxidant and anticoagulant activities. Journal of Applied Pharmaceutical Science 2(10): 1-10.

Selby HH \& WH Wynne. 1973. Agar. In: Whistler RL (ed). Industrial gums, polysaccharides and their derivatives, pp. 29-48. Academic Press, New York.

Shams El-Din NG \& MM Dorgham. 2007. Phytoplankton community in Abu-Qir Bay as a hot spot on the southeastern Mediterranean Coast. Egyptian Journal of Aquatic Research 33(1): 163-182.

Shams El-Din NG, AM Amer \& MA Abdallah. 2007. Study of natural components in some marine macroalgae in relation to nutrients along Alexandrian Coast, Egypt. Egyptian Journal of Aquatic Research 33(2): 87-112.

Shams El-Din NG \& ZM El-Sherif. 2012. Nutritional value of some algae from the north-western Mediterranean coast of Egypt. Journal of Applied Phycology 24: 613-626.

Singh RP, AJ Bijo, RS Baghel, CRK Reddy \& B Jha. 2011. Role of bacterial isolates in enhancing the bud induction in the industrially important red alga Gracilaria dura. FEMS Microbiology Ecology 76: 381-392.

Strickland JDH \& TR Parsons. 1972. A practical handbook of sea water analysis. Bulletin, Fisheries Research Board of Canada 167: 1-311.

Tang J, R Mao, MA Tung \& BG Swanson. 2001. Gelling temperature, gel clarity and texture of gellan gels containing fructose or sucrose. Carbohydrate Polymers 44: 197-209.
Villanueva RD, AMM Sousa, M Gonçalves, M Nilsson \& L Hilliou. 2010. Production and properties of agar from the invasive marine alga, Gracilaria vermiculophylla (Gracilariales, Rhodophyta). Journal of Applied Phycology 22: $211-220$

Wang G, L Shuai, Y Li, W Lin, XW Zhao \& DL Duan. 2008. Phylogenetic analysis of epiphytic marine bacteria on holerotten diseased sporophytes of Laminaria japonica. Journal of Applied Phycology 20: 403-409.

Whyte JNC, JR Englar, RG Saunders \& JC Linsay. 1981. Seasonal variations in the biomass, quantity and quality of agar from the reproductive and vegetative stages of Gracilaria (verrucosa type). Botanica Marina 24: 493-501.

Williams ST, ME Sharpe \& JG Holt. 1989. Bergeys manual of systematic bacteriology 4: 1-949. Williams and Wilkins, London.

Yaphe I \& GP Arsenault. 1965. Improved resorcinol reagent for the determination of fructose and of 3,6 anhydrogalactose in polysaccharides. Analytical Biochemistry 13: 143-148.

Yaphe W \& M Duckworth. 1972. The relationship between the structure and biological properties of agars. Proceeding of International Seaweed Symposium 7: 15-22.

Zaghloul FA. 1994. Phytoplankton dynamics in the Western Harbour of Alexandria, Egypt. Bulletin of National Institute of Oceanography and Fisheries ARE 20(2):107-117.

Zaghloul FA, RR Abdalla, HM Moustafa \& A Badr. 1995. Phytoplankton community structure in El-Dekhaila harbor of Alexandria. Egyptian Bulletin of National Institute of Oceanography and Fisheries ARE 21: 103-123.

Zobell CE. 1946. Marine microbiology, 240 pp. Chronica Botanica, Waltham. 